\title{
Legal Protection for Victims of Corporate Crimes In The Employment Field at Palembang City ${ }^{*}$
}

\author{
Burhanuddin \\ FSH UIN Syarif Hidayatullah Jakarta \\ Jl. Ir. H. Juanda No. 95 Ciputat Tangerang Selatan \\ E-mail: burhanudinmuhisam@uinjkt.ac.id
}

DOI: $10.15408 /$ jch.v5i2.7087

\begin{abstract}
:
Criminal sanctions which are imposed on corporations committing employment crimes as provided in Article 185 paragraph (1) of the Manpower Act are sufficiently burdensome for both corporations and corporate administrators since the culprit and alternative system of criminal punishment applied. It means that the corporate executives who commit crimes may be subject to imprisonment or criminal penalties or both of them. However, in practice law enforcement officers do not directly impose criminal sanctions in the form of imprisonment to corporate executives who commit crimes in the field of employment in this city due to the tendency of law enforcement officers to use the principle of subsidiary, namely the ultimum remendium position, it used because of consideration of economic reasons, the sanctions which are imposed only on administrative sanctions and criminal penalties and it closed to the normative rights of unloading of unloading labor.
\end{abstract}

Keyword: Legal Protection, Corporations, Employment

\footnotetext{
* Received: March 10, 2017, Revised: Mei 11, 2017, Accepted: Agustus 19, 2017.
} 


\title{
Perlindungan Hukum Korban Kejahatan Korporasi Dalam Bidang Ketenagakerjaan Di Kota Palembang
}

\begin{abstract}
Abstrak:
Sanksi pidana yang dikenakan kepada korporasi yang melakukan kejahatan di bidang ketenagakerjaan sebagaimana yang ditentukan dalam Pasal 185 ayat (1) UU Ketenagakerjaan sudah cukup memberatkan, baik bagi korporasi maupun pengurus korporasi, karena sistem penjatuhan pidana yang dianut adalah kumulatif dan alternatif. Maksudnya pengurus korporasi yang melakukan kejahatan dapat dikenakan pidana penjara atau pidana denda dan kedua-duanya yaitu pidana penjara dan pidana denda. Namun dalam prakteknya aparat penegak hukum tidak langsung mengenakan sanksi pidana berupa penjara kepada pengurus korporasi yang melakukan kejahatan di bidang ketenagakerjaan di Kota Palembang. Hal ini disebabkan karena adanya kecenderungan aparat penegak hukum menggunakan asas subsidiaritas, yaitu hukum pidana di tempatkan pada posisi ultimum remendium, dengan alasan pertimbangan ekonomis, sehingga sanksi dikenakan hanya sanksi administratif dan pidana denda serta menutup hak-hak normatif tenaga kerja saja.
\end{abstract}

Kata Kunci: Perlindungan Hukum, Korporasi, Ketenagakerjaan

How to cite (turabian):

Burhanuddin, Burhanuddin. "Legal Protection for Victims of Corporate Crimes In The Employment Field at Palembang City" JURNAL CITA HUKUM [Online], Volume 5 Number 2 (4 December 2017) 


\section{Introduction}

Employment issues are an interesting and actual problem to be analyzed; it's following the emergence of strikes and protests up to actions that lead to violence perpetrated by the workforce. the emerge of this some cases are indicated that there are still weaknesses in the regulation of labor issues, and it is resulting in the way of the employment in taking fast way outside the system that is not through the procedures which were set in the laws and regulations of labor. The occurrence of unrest among the workforce is inseparable from the fact that the manpower sector is less explored as a policy of government policy in the effort to increase economic grow th, even in order to attract foreign investors to invest their capital in Indonesia, Indonesian workforce is superior to the promotion of profit comparative, that is, the availability of a cheaper labor force compared to other countries and the incomplete labor-related regulations, especially on the rights to be gained by the w orkforce.

The heterogeneous of Indonesia's economic structure configuration tends to grow unfair competition as a result of free competition in the production and distribution process, leading to the development of monopoly, oligopoly, industrial concentration, market limitation or price fixing as a result of the crime perpetrated by corporations, who in their efforts to gain the maximum profit, at the expense of labor. ${ }^{1}$

The arising of the victim in the perspective of Victimology is defined as the victim is an individually or jointly suffers harm, including physical or mental injury, emotional suffering, economic loss or damage to his basic rights, caused by the actions of others who violate the criminal law in a country whether intentional or unintentional or negligent. In the other hand, the legislation in Indonesia has not been firm in regulating the actions of the corporation as a crime. The Criminal Code, hereinafter referred to as the Indonesian Criminal Code (KHUP), applies in Indonesia as a product during Dutch colonial rule, so that many cases arising as a result of rapid economic grow th have not been accommodated in the Criminal Code.

The corporation as the subject of law actually can be done in a provision outside the Criminal Code, although which can be criminal or subject to the law in the Criminal Code is a person, and then almost all the article in the

1 I.S. Susanto, Kejahatan White Collar dan Pembangunan Masyarakat Adil dan Makmur, Masalah-Masalah Hukum No.3, Fakultas Hukum Universitas Diponegoro, Semarang, 1991, p. 4 


\section{Burhanuddin}

Criminal Code begins with the word "whosoever".2 Although in criminal legislation outside the Criminal Code, some crimes have been regulated by the corporation as the subject of criminal law, so corporations that violate minimum wage provisions may already be brought to trial, but the reality is very difficult to implement. For example, the corporation that manages the loading and unloading workforce at the Port of Palembang is the Manpower Unloading Working Union, hereinafter abbreviated KTKBM, as an outsourcing corporation, with a total of 1,500 (fifteen hundred) loading and unloading personnel, divided into four ports namely Boom Port New Palembang, Special Docks PUSRI Corp., Special Port of PERTAMINA Corp Branch at Plaju and the Special Port of Sei Lais, Palembang.

It turns out that in the provision of wages, occupational safety and health, labor social security programs and severance/service payments do not conform to the Agreement of Tariffs of OPP/OPT, which have been drawn up and made between the South Sumatra Regional Board of Association of Indonesian Loading and Unloading Companies, the party representing the user of the loading/unloading worker with outsourcing worker/job recipient, hereinafter abbreviated DPW Sumsel APBMI, authorized by the Head of Port Administrator of Palembang which was gave to the Transportation office of Palembang City, the O Transportation office of South Sumatra Province and the General Director of Jakarta sea Transportation, ${ }^{3}$ But in the reality the corporations who against this agreement did not get punished. This is due to the fact that criminal law is not functioning properly in overcoming the crimes committed by the corporation. It should not be placed in the ultimum remedium position in the framew ork of subsidiarity principle to provide protection to the victim, but displayed in primum remedium ${ }^{4}$ position but with clear boundaries.

Considering to the victim's protection, the philosophical base is closely related to the purpose of the Republic of Indonesia, as set out in the Preamble to the 1945 Constitution of the Republic of Indonesia in the Fourth Paragraph, protecting the entire Indonesian nation and for the promotion of the general welfare. Therefore, to realize the legal protection of victims of corporate crime in the field of employment of the government issued, first, The Law Number 21 Year 2000 on Trade Unions, second, Law Number 13 Year 2003 on Manpower in

\footnotetext{
2 Mardjono Reksodiputro, Tindak Pidana Korporasi dan Pertanggungjawabannya, Perubahan Wajah Pelaku Kejahatandi Indonesia, Pidato Dies Natalis Ke 47 PTIK MABES POLRI, Jakarta, 1993, p. 4

3 Interviewed with Chairman of South Sumatra Regional Board of Association of Indonesian Loading and Unloading Company, Endar Himawan, SE. MM, on April 5 th, 2007

4 Sudarto, Hukum dan Hukum Pidana, Alumni, Bandung, 1981, p. 32
} 
lieu of Law Number Law No. 25 of 1997 on Manpower and it is referred to as the Manpower Law, which eliminates most of the laws which constitute the pillars of previous labor law or it can be argued that this law is a major step in "changing the playing field" between the parties involved employment matters ${ }^{5}$ and third, major changes to the labor dispute settlement system offered by Law Number 2 the Year 2004 on Industrial Relations Dispute Settlement is the abolition of Law Number 12 the Year 1964 concerning Termination of Employment in Private Companies and the replacement of Penye Committee the disputes of Labor Disputes under Law No. 22 of 1957 became the industrial relations dispute court. In the consideration of the Manpower Act stated that the legal protection of labor is intended to guarantee the basic rights of the w orkforce and ensure equal opportunity and treatment without discrimination on any ground to realize the welfare of the workforce and his family while still paying attention to the progress of the business side.

Thus, a matter that needs to be noticed in connection with the crime committed by outsourcing corporations as perpetrators of crime ${ }^{6}$ indicates there has been a development or shift on the perpetrators of crimes in the field of employment. The corporation of the corporation shall serve as the target or object or victim of a crime, whether relating to loading and unloading facilities or goods being worked on by the corporation of the employer (crime against corporations). However, in its development, corporations can also commit crimes or as perpetrators of crimes (corporation crimes) in the field of manpower, by among other ways reducing the healthy rights obtained by the loading and unloading w orkforce.

\section{The Role of Labor in Corporations}

As we know that labor as a resource is a major asset in realizing the existence of the corporation in addition to other assets such as financial and material. ${ }^{7}$ It turned out that this asset requires a different management with other assets, due to the potential nature. If the potential possessed by labor managed and well-constructed as the provision of training, welfare, and development, the workforce will be able to contribute greatly to the

\footnotetext{
${ }^{5}$ Marsen Sinaga, Pengadilan Perburuhan di Indonesia (Tinjauan Hukum Kritis atas UndangUndang PPHI), Perhimpunan Solidaritas Buruh, Yogyakarta, 2006, p. 3

${ }^{6}$ Eddy Rifai, Eksploitasi Buruh Sebagai Kejahatan, "White Collar", in daily magazine Suara Merdeka, Semarang, 19 November 1991, p. 7

${ }^{7}$ Mulyadi S, Ekonomi Sumber Daya Manusia Dalam Perspektif Pembangunan, Rajawali Pers, Jakarta, 2003, p. 191
} 


\section{Burhanuddin}

advancement of the corporation, although other assets less support. In this case, Julius Tahija said that "building labor is more important than building other resources".8

It is said that the workforce as a resource is potential because the workforce can generate added value for the development and progress of the corporation. The realization of the potential properties cannot be measured by numbers, but it is a process of interaction result of physical and psychological substance in the form of the ability to create, the ability to think that generates ideas, creativity, initiative, and problem-solving abilities, skills and expertise. Therefore these resources in order to survive and work in accordance with the demands of the corporation, it must be provided financing in exchange for w ork and their services.

The reward is basically at the same awards and rewards (reward) in order to contribute labor to the maximum in order to achieve corporate objectives. With these situations, it means employment in a corporation has a very important role and determine, so that its position as an asset, meaning that the costs incurred by the corporation relating to wages, means of labor and social security, training and development of workforce skills automatically function as capital, ${ }^{9}$ which is one factor supporting of the means of production, must be reckoned in the financing. The financing can be higher if the labor as a resource that is one of the assets of the corporation is scarce manpower; skills and expertise are limited in the labor market. Labor, as it requires the corporation to program and pay compensation, is competitive with similar corporations.

Furthermore, the workforce as a resource that is different from other resources have the potential physical and psychological unique and complex is an active subject, it is to encourage labor force participation is required capabilities corporations treat workers humanely, in the sense of respect and honor according to the dignity of humanity. Then, on the other hand are very important to realize and improve safety and satisfied for workers in carrying out the work, so motivated to improve performance such as hard work, loyalty and dedication are high, it needs to be realized, developed and constructed social relations at work dyed mutual respect, tolerance and being able to put any employment commensurate with their skills, position, and position. In positive social relationships, both in the formal and informal forms of

\footnotetext{
8 Julius Tahija, Manajemen Sumber Daya Manusia, Andi Offset, Yogyakarta, 2005, p. 18

9 A.M. Lilik Agung, Human Capital Competencies, Elex Media Komputindo, Jakarta, 2007,

p. 12
}

188 - Jurnal Cita Hukum. Vol. 5 No. 2, December 2017. P-ISSN: 2356-1440. E-ISSN: 2502-230X 
relationships will flourish into a sense of belonging a sense of belonging (sense of belonging), feeling partly responsible (sense of responsibility) and a willingness to participate (sense of participation). ${ }^{10} \mathrm{~W}$ ith such position, it will manifest an increase in both quantitative and qualitative product. ${ }^{11}$

\section{Law No. 13 of 2003 on Labor}

Among the prominent employment, the problem is the gap between the abundance of labor will be entered and need jobs, on the other hand, the limited ability to absorb the labor force. This reality there was a contradiction, on the one hand, human resources are the main capital in the development process, but on the other hand, these conditions can lead to a complicated problem. Every citizen has the right to work and a decent living. It means that the corporation may provide wages and other rights to the workforce must be in accordance with the collective agreement or employment rules of law, so as to meet a decent living for w orkers and their families.

As the implementation of Article 27 paragraph (2) NRI Constitution of 1945 , the government together with the Parliament to form labor legislation that aimed to provide a means of protection, legal certainty and to create a w orking relationship that is mutually beneficial for labor and corporations. Legislation in question is Act No. 13 of 2003 on Labor, hereinafter referred to Labor Law. In this law, governed the working relationship be harmonious, balanced and additionally expected to improve the welfare of workers and the survival and development of the attempt will be assured. All of this will lead to the success of the national development. How ever, after studied carefully about the Labor Law, there are three types of the employment on a work agreement agreed upon by the corporate workforce. The three types of the employment agreement are:

\section{First, the work agreement for an unspecified time}

According to this employment agreement, the agreement must be in writing. In the employment agreement containing at least name, address, employment, date of start working, occupation/position and wages including fixed allowances and benefits are not fixed such as meals, transport, and the two sides come face to face and required their probation labor, in practice for

10 Hadari Nawawi, Manajemen Sumber Daya Manusia untuk Bisnis yang Kompetitif, Gajahmada University Press, Yogyakarta, 1997, p. 43

11 Robert L. Mathis dan John H. Jakson, Managemen Sumber Daya Manusia, Buku I, Alih Bahasa Jimmy Sadeli dan Bayu Prawira Hic, Salemba Emban Patria, Jakarta, 2001, p. 277 


\section{Burhanuddin}

three (3) months and the corporation is required to pay in accordance with the applicable minimum. The labor agreement expires, according to Article 154 of the Labor Law, due to several things: a). Labor request a written resignation on their own without any indication of the form of pressure or intimidation of the corporation; b). Employment reached after retiring in accordance with the provisions contained in the company regulations, collective bargaining agreements or legislation; c). died; d). Labor is cut off by corporations.

Management or the corporate owner dies or switch right to the corporation that caused the sale, inheritance or grants, contracts that do not expire. The employment agreement ends due to the letters $a, b ; d$ workers to obtain severance pay, fees, and restitution, while the resulting, families of w orkers to obtain severance pay, fees as well as for workers who participate in the Social Security program obtain life insurance and collateral old days.

\section{Second, the Working Agreement for a Specific Time}

Workers who enter into labor agreements with corporations in this way in the community is known by the term contract labor, but in entering into labor agreements between the workforce and the corporation face to face. In the employment agreement at least by name, employment address, w ork start date, wages and other entitlements received and the term of the employment agreement expire, so that the rights and obligations of both parties can be clearly identified, not required for a probationary period. It is Required as a result of their probation, the status of labor agreements into employment agreements for an unspecified time. According to Article 59 paragraph (1) of the Employment, employment agreement for a specified time only made for specific jobs by type and nature of the job will be completed within a certain time, those are: a). A once-completed or temporary work; b). Work completion is expected in the not too long and not later than 3 (three) years; c). Seasonal work, and d). Jobs related to new products, new activities or additional products that are still in trial.

Furthermore, paragraph (2) states that the employment agreement for a specified time cannot be held for a permanent job. Referred to a specific period is a labor agreement can only be held for a maximum period of 2 ( $t w o$ ) years, and when the corporation will extend this agreement, then at least seven (7) days before the labor agreement expires has notified the point by writing to labor. Renewal may only be once times for a maximum period of 1 (one) year. In the event that the corporation will hold the renewal of labor agreement for a 
certain time, can be held after the exceeding grace period of 30 (thirty) days of the expiration of the old labor agreement, and can only be done 1 (one) time period of 2 (two) years. In the event that either party terminates the employment agreement before the expiration of the period specified in the employment agreement, the party terminating the employment agreement is required to pay compensation to another employee at the wage of the employee until the expiry of the term of the employment agreement, except; a). The Labor died, b). Expiration of employment agreement, c). Their specific circumstances or events specified in the employment agreement.

The term of the employment agreement for this particular period of time, the workforce does not earn severance pay or other fees, but in the practice the corporation only provides separation.

\section{Third, the contract of employment or the provision of labor services}

In employment contracting or employment services contracts, the workforce does not get into direct employment agreements with the employer corporation, but it has an employment agreement with the recipient corporation, called an outsourcing corporation. Here a triangular employment agreement is a work agreement between an outsourcing corporation and a workforce, and between outsourcing corporations with a company who use their service. In light of such contracts, all legal protections of the workforce such as wages, employment, and welfare facilities will be paid and received through outsourcing corporations. Regarding this matter is regulated in Article 64-66 of the Manpower Law. Article 64 states that a corporation may submit a portion of the work execution to another corporation through a contract of employment or the provision of labor services, which is made in writing. This provision is called outsourcing. Based on provisions above, outsourcing can be categorized into two ways:

a. Submission of a work by a corporation to another corporation to be employed elsewhere. The emphasis lies on the product material. For example, manufacture of buttons, nuts, and keys on the machine automotive corporation.

b. Provision of corporatelabor services by the employment service, which is employed in other corporations that need. The emphasis on the individual need. For example, the corporation will carry out the loading-unloading rubber amid the Musi River-Plaju, workers unloading drawn from corporate outsourcing. 


\section{Burhanuddin}

Based on the results of research that the authors did, about the implementation of outsourcing in Port of Palembang can be explained, that the corporation who use the service of loading and unloading, then it is abbreviated as PBM, before carrying out activities of loading o goods from one ship to another they must enter a cooperation agreement with KTKBM in form of written agreement. In that document, it is contained of the Ship Name; Date/time of unloading/loading begins, Workplace, Number of requested TKMB. After that it was signed by both parties, at the same time PBM handed the fund as persecute at least $25 \%$ of OPP / OPT $x$ the amount of goods to be unloaded based on International Maritime Organization (IMO) special disturbing goods such as cement, fertilizer, salt, tapioca flour, sour tamarind and sodium soleplate are subject to $20 \%$ surcharges of very dangerous goods such as butane, formalin, petroleum product subject to $100 \%$ surcharges and dangerous goods such as waste paper, cotton, iron oxide are subject to $50 \%$ surcharges. If the requirements have been fulfilled by PBM, KTKBM shall issue a Work Order Letter to the Head of Work Team and TKBM to carry out the loading/loading of goods from and/or to the ship. Work dismantling or loading of goods is finished; PBM must pay the remaining wages by $75 \% .^{12}$

Noting to the working relationship, the PBM does not have a w orking relationship directly with workers unloading, but PBM can only govern and give jobs to workers unloading is corporate outsourcing, so that loading and unloading labor and the wages paid and all rights of corporations outsourcing. On the legal protection of the loading and unloading labor force, based on the results of the research, the w riter can be explained that as the implementation of the mandate of Article 66 Paragraph (2) of the Manpower Law, the Chief Administrator of the Port of Palembang instructs the Chairman of the South Sumatra Regional Executive Board of the Association of Indonesian Loading and Unloading Company -Same with the Chairman of the Cooperative Stevedoring Palembang arraged the Rates of OPP / OPT in Port of Palembang. Compilation Rates OPP / OPT must be based on the Labor Law and the Regulation of the Minister of Transportation Number 35 the Year 2006 on Guidelines for Tariff Calculation Stevedoring Services Goods From and/or To ship in the port.

In the OPP / OPT cost it not only regulates wages, but also other rights received by labor such as welfare in the form of work clothes, work shoes, helmet, gloves, masks and insurance in the form of work accident insurance,

12 The interview with the Chairman of the South Sumatra Regional Board of Indonesian Association of Loading and Unloading Company, on January 7th, 2008. 
death insurance, old age pension, health care benefits and severance pay/service fees. Preparation of OPP / OPT Tariffs is agreed upon by both parties, set forth in the Agreement of Agreement between the Corporation of the Bongkar Muat Officers and the South Sumatra Regional Board of Association of Indonesian Loading and Unloading Company Number: KP. In order to legalize this agreement, the Head of the Administrative Office of the Port of Palembang was transferred to the Department of Transportation of South Sumatera Province c / q Sea Transportation Section and the Director General of Transportation Sea of the Jakarta Transportation Department. The legal protections of loading and unloading labor that should be provided by an outsourcing corporation are:

\section{- Protection of Wages}

In the consensus of the agreement the collective agreement affirmed that wages play a very important role and is a hallmark of a working relationship, it can even be said wage for the loading and unloading labor as the main goal in doing the work, received in the form of money with the amount according to the agreement.

Furthermore, regarding the system of payment of wages by way of wholesale or lump sum, meaning that the workforce loading and unloading of wages do not take into account the time carry out the work. For example, w orkers carry out the demolition cement unloading of the ship KM. Intan Perita 1,000 tons, usually when it is not raining cement demolition is completed within 24 hours, because of the rain demolition is completed to 48 hours. In this case, the loading and unloading labor still receives wages such as no rain or no additional wages.

\section{- Protection of welfare}

In agreement collective it is stipulated that before workers conducting demolition or loading of the goods and/or to the ship are required for corporate outsourcing to protect the welfare of such work clothes, work shoes and helmet twice a year, gloves and masks can have a new one in every new job the old one should be returned.

\section{- Insurance Protection}

In the life of loading and unloading labor, they often get a risk when they are carrying out activities of dismantling or loading of goods from and/or to the vessel, which may cause physical or material harm as has happened at the time of them. Such as carrying out the activities of unloading the wire rod from the vessel to the top of the truck suddenly each carrier wire rod broke and 


\section{Burhanuddin}

hit the w orkforce resulted in labor unloading died. To deal with such cases, in a mutual agreement it is stipulated that outsourcing corporations are required to include all loading and unloading workers in the social security program of labor.

\section{- Severance and service fees}

According to the Article 15 about the mutual agreement, that the event of termination of employment due to labor unloading retire or resign from the membership of corporate outsourcing, with a quadruple mass employment of at least 5 (five) years, corporate outsourcing required to provide severance pay or fees. ${ }^{13}$ But after the author confirmed by several workers unloading through the direct interview, it turns out the information given by the Chairman of the Cooperative Stevedoring Wyoming are not in accordance with the implemented in the field, so it can be identified crimes committed by corporations against w orkers unloading are:

\section{- Protection of Wages}

According to the Head of the Employment Team "Kemet' the crime committed by the corporation, make wage deductions when the Head of the Working Group takes wages in the finance department. "Modus operandi" for example, outsourcing corporation gets the job from loading and unloading company to carry out the activity of demolition of SP36 fertilizer from the ship as much as 5,500 tons. Then the outsourcing corporation instructs the Head of the Working Team to carry out the dismantling of the fertilizer. In accordance with the agreement of the w ork completed the loading and unloading company pays the wages to the outsourcing corporation according to the OPP/OPT tariff of $(5,500$ ton X Rp.5.692) + (20\% x Rp 31.306.000) = Rp. 37.567.200, - It turns out that the wage received by the Head of the Working Team of the outsourcing corporation is $37,567,200-(37,567,200 \times 20 \%)=$ Rp. 36.815.856. Wage reduction is done by the Chief Financial Officer in cooperation with the Head of Operations. The crime has long been done by outsourcing corporations, i.e. since 2005. Furthermore, He said that they had asked the two officials about the wages received less. The two officials replied that the money was used for additional operational costs. For such an answer, we cannot do much, this is due to our position, on the weak side of the economy, education and on the other hand it requires work to support the family. Because to work elsewhere (not as a workforce of loading and unloading) is not possible, the education we

13 The interview with the Head of Koperasi Tenaga Kerja Loading \& unloading Palembang, H. Saendang, on January 10th, 2008 
have is only up to elementary school. If the crimes of both outsourced corporate officers are reported to the Palembang Port Administrator or the Port Security Police Force of Palembang Port, we are afraid of being terminated as outsourced corporate members, meaning they can no longer w ork in the Port. ${ }^{14}$

\section{- Welfare protection}

For five years the outsourcing corporation did not provide welfare for workers in the form of work clothes, work shoes, helmets, masks and work gloves so that the loading and unloading labor when carrying out loading and unloading activities from and/or to the vessel does not use the proper work facilities. 15 While the loading and unloading work at PUSRI Corp. And PERTAMINA Plaju meets safety requirements. This is because there is pressure from the two special docks if the loading and unloading labor does not use the work facilities as stipulated by both of those companies. The Workers are not allowed to carry out loading and unloading activities. ${ }^{16}$

\section{- Insurance coverage}

Apparently the outsourcing corporation does not include all the Chief Workers and unloading workers in the social security program of labor, but only partially. If the loading and unloading worker has an accident while carrying out the demolition or loading of goods from and/or to the vessel, the cost for treatment at the hospital is temporarily charged to the Head of the Working Team. After that the Head of the Working Team reports the event of an accident to the outsourced corporation, the expenses incurred by the first Head of the Working Team and if the workforce of loading and unloading in the hospital is the responsibility of the outsourcing corporation, but after the loading and unloading work of the hospital and go to work-loads of selfloading and unloading w ork assisted by the Head of W orking Team.

In addition, if they got accident but not to stay in the hospital, outsourcing corporation won't replace all expenses incurred, but with the classification, which is more than Rp. 250,000 (two hundred and fifty thousand) are reimbursed only Rp. 250.000 (two hundred fifty thousand rupiahs), less than Rp. 250,000 (two hundred and fifty thousand rupiahs) is replaced entirely. 18th, 2008

${ }^{14}$ The interview with the Head of Boom Baru Port Working Team, Kemet, on January 17-

15 The interviewed with the Head of Boom Baru Working Team Junaidi, on January 2022th, 2008

16 The interview with the head of the Working Team Special Pier PT.Pusri, Sugiarto, on January 10th 2008 and the Head of the Work Team S pecial Pier Pertamina Plaju, Bakir, on December 17th, 2007 


\section{Burhanuddin}

As for the family of loading and unloading work the corporation's pain has never replaced the cost. ${ }^{17}$

\section{- Severance pay or service fee}

Head of unloading worker who resigns or is dismissed from outsourced corporate membership due to age of old or permanent disability due to work accident so that it cannot carry out the work, outsourcing corporation does not provide severance and / or service fee as specified in Article 15 of the Agreement The Joint Agreement, even though the loading and unloading workforce has been working for 10 (ten) years or 20 (twenty) years, but it only provides only modest. ${ }^{18}$

\section{Analysis of Decision Number: 23/G/2006/PHI-PLG}

According to the Industrial Relations Court Judge at the Palembang District Court of IA class, that disputes between labor and corporation may occur proceeded by violations of law, and may also occur because they are not violations of law. Employment disputes resulting from violations of law are generally due to:

- There is a difference of understanding in the implementation of labor law. This is reflected in labor or corporate actions that violate labor law provisions. For example, among others, corporations pay wages under the wages of collective agreements or labor legislation.

- Discriminatory corporate actions. For example, job title, occupation, education, the same period of work but because of differences in politics, religion, and ethnicity are treated differently.

While labor disputes that occur without preceded by abuses are generally caused by a lack of understanding of changes in terms of employment, for example, labor demands wage increases, food allow ances, and transport money but corporations disagree. ${ }^{19}$

Furthermore, the Industrial Relations Court Judge at the Palembang District Court of IA class explained that now there is only one outsourcing case

17 The interview with Mandor Palka of Boom Baru Port, Mawi, Tawan, and Husin, on December 22th, 2007

18 The interview with the the Head of Boom Baru Port Working Team, Bantong, and Sukri, on January 27th, 2007

19 The interview with the Industrial Relations Court Judge at the Palembang District Court of Class IA, Hermawan, SH, on January 13th, 2008 
that has been examined and decided by the Industrial Relations Court at the First Class Court of Palembang with Decision No. 23 / G / 2006 / PHI-PLG dated October 16, 2006, for the crime of PT. Ade Pass's son against his workforce related to wage issues. Sitting his case as follows:

Considering whereas the plaintiff with the letter of his lawsuit dated June 26, 2006, which has been registered with the Court of Industrial Relations Court at the First Class Court of Palembang, on 27 June 2007 with register No. 23 / G / 2006/PHI-PLG has filed the following:

1. The plaintiff is a worker who has worked 5 years ..... in the Defendant for the exploitation and crude oil production of Technical Assistance Conduct (TAC) of Pertamina-Pilona Petro Tanjung Lontar Ltd, through a service provider company manpower i.e. PT. Son Ade Pass;

2. The activities of the plaintiffs are the main activities of crude oil drilling, this is directly related to production;

3. The hiring of the plaintiffs by the Defendant I Management, through the service provider company of Defendant II and Defendant III, is contrary to the law stipulated in Article 65 paragraph (2) letter a, letter c and letter d juncto Article 66 paragraph 1) of the Manpower Law;

4. The plaintiffs who carried out security activities were classified by Defendant I and Defendant II as security assistants (security assistants) whereas the plaintiffs who conducted security activities since working with Defendant I had no written agreement and the plaintiffs were accepted to w ork by Defendant I directly;

5. Getting the legal status of the employment relationship between the plaintiffs and the employers of the employment services has turned into a working relationship between the plaintiff and the employer company (Defendant I), in accordance with the provisions of Article 65 paragraph (3) juncto Article 66 paragraph (4) Of the Manpower Act.

6. The plaintiffs have complained to the mediator for the mediation of rights disputes and according to the employees of the Lahat District Manpower Office set out the deficiencies of normative rights:

a. Defined as a permanent worker in Technical Assistance Concern (TAC) Pertamina-Pilona Petro Tanjung Lontar Ltd;

b. Assigned a security guard to a security guard and appointed as a security guard TAC Pertamina-Pilona Petro Lontar Cape Ltd Corp; 


\section{Burhanuddin}

c. The deficiency of the normative rights is lack of payment of wages in 2005 which is not in accordance with SKGM PERTAMINA DOH South Sumatera Number: 046 / D13000 / 2005-58;

d. Stipulated repayment of food money to each worker who since February 2006 cut by Rp. 75.000, - that must be accepted by the w orkforce Rp. 225.000, - cut to Rp. 150.000, -

e. Stipulated for a worker who is applying for a pension and over 55 years of age is entitled to a 2 (two) term severance with his tenure computed from the very beginning of his employment at service provider company, TAC Pertamina Pilano Petro Tanjung Lontar Ltd.

7. That the plaintiffs received this recommendation and submitted in w riting to the Lahat Regency Manpower Office;

8. Defendant I, Defendant II and Defendant III have not fulfilled the recommendation, even the Defendant I manager has made an announcement to receive the workforce and is now working on Defendant I;

9. Whereas the actions of the Defendants II and Defendant III employing plaintiffs in unemployed labor service companies, classified security guards as security assistants and paid wages not in accordance with SKGM Pertamina DOH South Sumatera in 2005 and cut allowances meal money of Rp. 75.000, - since February 2006, has been detrimental to the plaintiff that the plaintiff suffered a loss and on this occasion the plaintiffs demanded compensation in the form;

a. Lack of payment of wages in 2005 which became the rights of the plaintiffs in accordance with SKGM PERTAMINA DOH South Sumatera Number: 046/13000 / 2005-58 Rp. 65,349,624 (Sixty-five million threehundred forty-nine thousand six hundred and twentyfour rupiahs).

b. The lack of payment of food allowance as of February 2006 amounted to Rp. 35,500,000 (Thirty-five million five hundred thousand rupiahs);

c. Whereas in the management of industrial relations disputes, the costs incurred by the plaintiffs during this process are running at Rp. 15.000.000 (fifteen million rupiahs). 
10. That the plaintiffs are prejudiced against the Defendant will not comply with the decision of the law, especially when this has been circulated the news submitted by Br. User Defendant I that the workforce will be rescued from the beginning of August 2006, even the Defendant has made an announcement to receive the workforce, so to ensure that this decision is well implemented, please the panel of judges who examine this dispute in order to place confiscation warrant (conservatoire beslag) to the property of Defendant I, Defendant II and Defendant III in the form of:

a. Bills in August 2006 and September 2006, the sale of crude oil ow ned by the Defendant I which has been and/or will be billed to PERTAMINA DOH South Sumatera Corp. in Prabumulih, South Sumatera, for the number and date of the above mentioned bill is in Defendant I;

b. The August 2006 and September 2006 bills for payment of the services of Defendants II and Defendant III which have been and/or billed to TAC Pertamina-Pilona Petro Tanjung Lontar Ltd for the number and date of the invoice are in Defendant II and Defendant III.

11. That in order to prevent Defendant I, Defendant II and Defendant III negligent, or to avoid the content of the decision in this case, the plaintiffs appeal to the Chairman of the Industrial Relations Court at the First Class Court of Palembang to punish Defendant I, Defendant II and Defendant III to pay the money by force to the plaintiffs it was about Rp. 3.950.000, - (three million nine hundred and fifty thousand rupiahs) for each day of delay in carrying out the content of the decision in this case.

Based on the description above and legal facts, please contact the Chairman of the Industrial Relations Court at the Palembang District Court of IA Palembang c / q The Panel of Judges who examined the dispute to decide on the following:

\section{PRIMARY}

1. To declare the acceptance and grant of the plaintiff's claim in its entirety; 


\section{Burhanuddin}

2. To declare the acts committed by Defendant I to hire manpower through a service provider company in the Company of Defendant II and Defendant III against the plaintiffs themselves as unlaw ful acts;

3. To declare the actions of Defendant II and Defendant III to classify security officers as auxiliaries is against the law;

4. Punishes Defendant I to appoint laborers employed by employment service providers in Defendant II and Defendant III firms at TAC Pertamina-Ilona Petro Tanjung Lontar Ltd;

5. Punishing Defendants I and Defendant III to appoint security auxiliaries to permanent safeguards at TAC Pertamina-Pilona Petro Tanjung Lontar Ltd;

6. Punishing Defendant I, Defendant II and Defendant III pay in cash the shortage of wages to the plaintiffs of Rp. 65,349,624 (sixty-five million three hundred forty-nine thousand six hundred twenty-four rupiah);

7. Punishing Defendant I, Defendant II and Defendant III paid in cash for lack of money to the plaintiffs since February 2006 of Rp. 35.500.000, (thirty-five million five hundred thousand rupiah);

8. Punishing Defendant I, Defendant II and Defendant III pay the cash expenses incurred by the plaintiffs during the process of this dispute run to the plaintiffs of Rp.15.000.000, - (fifteen million rupiah);

9. Punishes Defendants I, Defendant II and Defendant III to pay for forced (dwangsom) for each day of delay in executing the decision in this dispute to the plaintiffs of Rp. 3.950.000, - (three million nine hundred and fifty thousand rupiah);

10. Placing confiscation of property owned by Defendant I, Defendant II and Defendant III in the form of:

a. The August and September 2006 they claimed of the sale of Crude I owned crude oil which has been and/or will be billed to PERTAMINA DOH Corp. of South Sumatera in Prabumulih, South Sumatra, for the number and date of the invoice is in Defendant I;

b. The August and September billing services of the Defendant II and Defendant III providers of workforce that have been and/or will be billed to TAC Pertamina-Pilona Petro Tanjung Lontar Ltd for the above number and date of the invoice are in Defendant II and Defendant III; 
11. Order the Trial of the Industrial Relations Court at the State Court of Class IA of Palembang to confiscate the property assets of Defendant I, Defendant II and Defendant III in the form of;

a. The August and September 2006 claims of the sale of Crude I ow ned crude oil which has been and/or will be billed to PT. Pertamina DOH South Sumatera in Prabumulih, South Sumatera, for the number and date of the above-mentioned bill is in Defendant I;

b. The August and September billing services of the Defendant II and Defendant III providers who have been and/or will be billed to TAC Pertamina-Pilona Petro Tanjung Lontar Ltd for the numbers and dates are in Defendant II and Defendant III.

12. To declare the validity and security of taking guarentee for property owned by Defendant I, Defendant II and Defendant III placed by the Chairman of Industrial Relations Court at the First Class Court of Palembang;

13. Punishing Defendant I, Defendant II and Defendant III to pay case fee;

14. Declare This ruling may be carried out in advance even if there is a verification verdict (uitvoerbaarbijvoorrad).

\section{SUBSIDIARY}

If the Chairman of the Industrial Relations Court at the Palembang District Court IA Palembang c / q The Ad Hoc Panel of Judges of the Industrial Relations Court who examined this case argued otherwise, please the fairest verdict (ex aeguo ET bono). Considering whereas in the prescribed trial are present:

For the plaintiffs attended by representatives of the plaintiffs who are also the principal plaintiff A. Eka Mardani, Endang Darmawan, Rohimi AR, Juliansyah, Fahmi Hernaw an, Suhardi is SBB Executive Board PPTI Ltd ---------

For Defendant I proxies Advocate / Lawyer Hardiansyah HS, SH corresponding authorization letter dated 23 August 2006, for the Second Defendant and Defendant III comes proxies Advocate / Lawyer Maryani Yazid, SH corresponding power of attorney on 1 September 2006, at the next session Second Defendant was present principal director Main PT. Ade Putra Pass, Alamsyah, SH for Defendant III present the power of President Director namely 


\section{Burhanuddin}

Director of PT. Son Ade Pass, Alamsyah, SHaccording to the power of attorney dated September 8, 2006

Considering that the Panel of Judges has tried to reconcile the two sides who have gone to court but have not succeeded. Then the examination of the case was continued by reading the Plaintiff's Claim Letter dated July 25, 2006, and to the law suit. The Plaintiff stated that it remained with his law suit In consideration of the Panel of Judges are as follows: Considering whereas the exception of Defendant I has been declared accepted and granted by the Panel of Judges, then Defendant I must be removed from his position as Defendant

Considering whereas the Panel of Judges has declared rejected the exception lawsuit filed by Defendant II and Defendant III, the Court shall further consider the plaintiff's law suit in the principal issue of the case

Considering that the plaintiffs in the law suit posita has sued Defendant Defendant II and III of the deficiency payment of wages during the period of the year 2005, where there has been a difference in the wages received by the plaintiffs were not in accordance with the provisions SKGM Number: 046/130000/2005/58 with a nominal amount of underpayment of Rp. 65,349,624 (sixty-five million three hundred and forty-nine thousand six hundred and twenty-four rupiah), as well as the plaintiffs, have sued both Defendant II and Defendant III to pay for the lack of food allow ance of Rp. 35.500.000, - (thirtyfive million five hundred thousand rupiah) -----

Considering whereas prior to considering the substance of the subject matter of the lawsuit sued by the plaintiffs, the Panel of Judges deems it necessary to consider the legal subject of the litigants in advance

Considering that the plaintiff is a workforce that works on the Second Defendant and Defendant III, thus the claimant's legal relationship in the form of a working relationship with the Second Defendant and Defendant III, it has been proved that there are three elements that must be met for their employment by Defendant Defendant II and III (Article I point 5 of the Labor law), then when the plaintiffs feeling and experiencing the shortage of payment of wages and the lack of payment of meal allow ance is reasonable if the plaintiff has made the second Defendant and Defendant III as legal subjects were sued by the Plaintiff- 
Considering whereas the plaintiffs in the posita of claim number 7 letter $b$ and letter c clearly demand and charge the Defendant II and Defendant III to pay for the deficiency of the normative rights of lack of food allowances and the shortage of wages with the amount of nominal value as mentioned above, but in the petition lawsuit primary figures 6 and 7 of the plaintiffs have entered other parties, namely the Defendant I that no one called in posita lawsuit, so between posita and petitum law suit becomes unclear (absocuur libel), in which the plaintiffs in primary lawsuit petition had sued the Defendant I, Defendant II, and Defendant III, then the judges concluded that the arguments of the lawsuit plaintiffs who claimed their reward deficiency for Defendant I, Defendant II and III of the Defendant must be declared NOT ACCEPTED ------ -

Judges' Decision on the Principal Case -----------------------------------

1. To declare the plaintiff's claim against Defendant I unacceptable;

2. To declare the plaintiff's law suit against Defendant II and Defendant III on the petition of the primary suit number 6 and number 7 is unacceptable;

3. Rejecting the plaintiff's claim other than and beyond;

4. All costs incurred in this case to the State of Rp. 0,

The authors comment on the Judges' Decision in the case above it is inappropriate, the Judges should have granted part of the plaintiff's sued to Defendant II and Defendant III, namely the shortage of wages, even in the plaintiff's claim to include Defendant I as a defendant. Because in the consideration of the Panel of Judges that the Panel of Judges has received the exception filed by the Defendant I, then Defendant I must be removed from his position as a defendant. Furthermore, in accordance with Article 65 paragraph (4) of the Manpower Act which was stipulated that the protection of work and labor requirements for labor in other companies at least equal to the protection of work and terms of employment in the employer company or in accordance with the legislation applicable?

\section{Corporate Criminal Accountability against Employment Crime}

Corporate criminal liability cannot be separated from the actions committed by corporate executives, which is constructed as an act and a mistake on the corporation because the actions and errors in the corporation are 


\section{Burhanuddin}

always manifested through human acts of the corporate management. A delegation of accountability from human actions becomes acts and mistakes to the corporation. This can happen if the act falls within the scope of the corporatew ork. Regarding this matter in criminal law is known by the term as a functional performer. Thus it can be said that the acts and mistakes committed by the board can be accountable to the corporation because the board in doing not do it on the right of its own authority, but on the rights or authority of the corporation. It means that corporations cannot escape the mistakes made by the board, while the deliberate or negligence (culpa) of the board must be regarded as the deliberate or negligence of the corporation itself.

As already said, corporate actions are always manifested through human actions. Responsible human actions to the corporation should be separated between the board, the person outside the corporate management but having the authority to represent the corporation based on the articles of association, and those representing the corporation differently. Regarding the latter, in practice, there are often physical offenders who can naturlijkpersoon or rechtspersoon who are organically unrelated to the corporation allegedly committed a crime. In this case, the construction used is the construction of civil law concerning representation or authorization. Through legal construction, which actually leads or gives orders that are the person in the corporation, then the actions of others that can be accountable to the corporation concerned. Understanding of corporate responsibility as the legal subject of criminal offenses cannot be separated from errors in the widest sense and penal sanctions.

\section{Corporate Corruption Error}

Discussing the mistakes in criminal law it errors that can be distinguished from two meanings that are psychological errors and errors that are normative. A psychological error is a mistake that is only seen as the psychological (inner) relationship between the maker and his actions. Such inner connection can be either deliberate or negligent. In deliberate, the inner relationship of wanting deeds and their consequences, whereas in the negligence does not want such a thing. So it's only the inner state of the maker, whose size is the inner attitude of the will to action or effect.

In contrast to the normative errors, which determine the mistake of the maker not only based on the inner attitude or the inner relationship between the maker and his actions but in addition, there must be an element of 
judgment or the normative element of his actions. Normative assessment means an external assessment of the relationship between the maker and his actions. This external assessment is a defense by using the measures contained in society, is what should be done by the maker. In these terms the maker's inner attitude is deliberate and negligence is noticed, but merely an element of error or an element of criminal responsibility. In addition, there is another element is the assessment of the state of the soul of the maker of the ability to be responsible and the absences of reasons eraser errors are.

The mistake is the state of the soul of the maker and the inner connection between the maker and his deeds. The existence of a mistake on a person, then the person can be reproached. Regarding the state of the soul of the maker who commits a criminal act is called responsible ability, while the inner relationship between the maker and his actions is deliberate, forgetful and forgiving reasons. Thus to determine the error of the manufacturer the following elements must be met: a). The existence of a responsible ability on the maker; b). Error, the inner connection between the maker and his deeds of deliberate (dolus) or negligence (culpa), and c). No eraser reason or no forgiving reasons.

Based on the description above, the mistakes made by the corporation such as reducing wages and other rights to the loading and unloading workforce can be categorized as a normative error, because it is only aimed solely to achieve profit or meet corporate targets resulting in the life of the w orkforce dismantling fit and his family suffered. Therefore, the mistakes made by outsourcing corporations are actions that are contrary to law, justice, and disgrace. The results of interview ed that the authors did, for crimes committed by outsourcing corporations to w orkforce loading and unloading in the Port of Palembang associated with the issue of wage reduction and other rights made by corporate administrators outsourcing with Head of Port Administrator Palembang can be clearly known, that the status of power w ork of loading and unloading at Port of Palembang is as a member of outsourcing corporation, hence loading and unloading labor receive wages and other rights from outsourcing corporation received from employer company. If the indication of wages and other rights received by the loading and unloading w orkforce of an outsourced corporation does not conform to the Joint Agreement on Tariffs of OPP / OMO, then those responsible for the acts committed by the official in the outsourcing corporation are outsourced corporations, since the official is to engage in such acts within the scope of the work provided by the outsourced corporation, although the acts committed by the official, in this case, the chief 


\section{Burhanuddin}

financial officer, and the operations department, are not the policies of the outsourcing corporation.

So to make the effectiveness of the outsourcing provisions as set out in the labor legislation, the outsourcing corporation that commits an error shall replace or close all the wage deficiencies received by the loading and unloading w orkforce for the acts committed by the offending official, without the need for verification, and if the outsourcing corporation does not carry out the fulfillment of obligations until the deadline has been agreed, the Chief Administrator of Port of Palembang due to the position will delegate the case to the Police Executor of Port of Palembang. ${ }^{20}$ While the results of interviewed that the authors did in the Office of the Regional Executive Board of Confederation of All Indonesian Workers Union of South Sumatra province with the legal section can be known that all workers who entered into a w orking relationship with the corporation either through a work agreement for in a certain time or a work agreement for a certain time as well as employment contracts and the provision of employment services, receive rights not in accordance with labor laws or collective agreements, due to errors, whether due to intent or omission, done by the corporation, the w orkforce shall report to the SPSI board anywhere, the workforce is not yet a member of SPSI. SPSI's b oard that receives the report will follow up, by going to the company where the workforce works. This is to enforce the effectiveness of the laws of labor legislation in the company. ${ }^{21}$

In addition, the results of research that the authors conducted in the Labor Office of Palembang City with Civil Servant Investigator obtained data that to solve the employment case in the city of Palembang always use the principle of vicarious liability. According to him, if there are w orkers reporting the issue of normative rights to the Manpower Office of Palembang City, for example receiving wages that are not in accordance with collective agreements or labor legislation regulations, then corporate administrators immediately called to be questioned on reports from labor. If the report of the workforce is true, the corporation is required to be held accountable for its misconduct, even

20 The result of an interview with the Chief Administrator of Port of Palembang, Drs. M. Syarif Effendi, B.sc, on 27 January 2008

21 The interview with the Legal Division of the Regional Executive Board of the Confederation of All Indonesian Workers of South Sumatra Province, Teguh Zindi, and Syahroji Karta SH, SH, on January 26-27 th 2008. 
if it is not the will of the corporation but the deeds of its officials without the knowledge of the corporation. ${ }^{22}$

Based on the results of above $r$, it is obvious that in an effort to provide legal protection against labor for crimes committed by the corporation both the Chief Administrator of Port of Palembang and the Office of Manpower of Palembang City always use the principle of vicarious liability. This is because the employment case that usually commits the crime is the board of the corporation itself, and executes the crime using the authority granted by the corporation, so to solve the case the above government apparatus does not have to prove the mistake of the maker.

\section{Criminal Sanctions against Corporations}

Criminal sanctions are one means to combat crimes committed by corporations, which are generally intended for the welfare of the community, while specifically providing protection to labor. However, the use of criminal sanctions against corporate crime is often associated with financial, but actually contains a broader purpose. In this regard, the problem is choosing and establishing appropriate criminal sanctions as a means of tackling corporate crime must necessarily take into account the factors that support the operation of criminal law in reality, including the motives of economic corporation crime. For it must be admitted that not all types of crimes can be imposed on corporations. As examples of capital punishment, imprisonment and imprisonment are crimes types that cannot be applied to the corporation, because these types of crimes can only be imposed and lived by a human, and the type of criminal that can be imposed on the corporation is only a fine of fines.

Selecting and enforcing crime by considering costs and results, as well as economic motives, can be regarded as an economic approach. The economic approach here is not only intended to consider the costs or burdens that the community bears with the outcomes to be achieved, but also in the sense of considering the effectiveness of the criminal sanctions itself as an economic preventive means when the following conditions are met: a). The penalty really prevents; $b$ ). The penalty does not result in a more harmful or harmful situation that would have occurred if it had not been imposed; c). There is no other option that can prevent effectively with less harm or loss.

\footnotetext{
22 The interview with the Civil Service Investigators at the Office of Manpower Office of Palembang City, Burlian, SH, on February 2nd, 2008
} 


\section{Burhanuddin}

Based on the results of interview ed that the authors did with the Head of the Security Police Force of Port of Palembang, ${ }^{23}$ Industrial Relations Court Judge at the Class IA Court of Palembang ${ }^{24}$ can be seen that criminal sanctions imposed to corporations who committed crimes in the field of employment in Palembang City as specified in Article 185 paragraph (1) The Manpower Act is sufficiently burdensome for both corporations and corporate executives since the adopted criminal system is cumulative and alternative. It means that the corporate executives who commit crimes may be subject to imprisonment or criminal penalties and both imprisonment and fine. Article 185 paragraph (1) of the Manpower Act stipulates whoever commits an offense as referred to in Article 86 paragraph (1), Article 90 paragraph (1), Article 91 paragraph (2) and Article 156, shall be imprisoned for at least 1 (one) year and maximum 4 (four) years and/or a minimum fine of Rap. 100.000.000, - (one hundred million rupiahs) and at most Rp. 400,000,000, - (four hundred million rupiah).

If these sanctions are actually enforced it can prevent outsourcing corporations from committing crimes in the employment field, and the loading and unloading work is not treated haphazardly by outsourcing corporations, so that their life will become viable as mandated by the Preamble of the 1945 Constitution and Article 27 paragraph (2) Of the 1945 Constitution. However, after the authors conducted a study by examining the case book that entered both the Security Police Executing Agency of Palembang and the Palembang City Police Force, until now there has been no outsourcing cases that come in both law enforcement agencies, although based on information that researchers get in the field, both from unloading and unloading, outsourcing corporations when making wage payments to unloading workers are always reduced or under the wages of OPP / OPT Tariffs as agreed in the collective agreements, as well as on other rights. From the explanation above, if analyzed by law enforcement officers do not directly impose criminal sanction in the form of imprisonment to corporate executives who commit crimes in the field of manpower in Palembang city because of the tendency of law enforcement officers to use subsidiary principle, that is criminal law is placed in ultimum remendium position, economic considerations, so that sanctions are imposed only administrative sanctions and criminal penalties and close the normative rights of unloading labor. Therefore, for the protection of labor law of loading and unloading of corporate crime can be realized, it is necessary to consider the

${ }^{23}$ The interviewed with the Head of the Port Security Police Executive of Palembang, AKP Ali Sadikin, SH, on January 29th, 2008

${ }^{24}$ The interview with the Industrial Relations Court Judge at the First Class Court of Palembang, Hermawan, SH and Sudirman, SH, on January 13th, 2008 
position of criminal law in the premium remedium position for outsourcing corporations who commit crimes in the field of labor. For outsourcing, corporations have a tendency to commit crimes.

\section{Conclusion}

As an effort to provide legal protection for loading and unloading labor against corporate crime in the field of employment in Palembang City, the principle of vicarious liability is used, in which outsourcing corporations are liable for errors committed by the board or senior officer while still in the scope of work or authority, conducted by the board or senior officer is not part of the policy of the outsourcing corporation. While the nature of corporate criminal responsibility to account for the mistakes made by the board or senior officer, using the nature of the corporation as the maker, responsibleboard. In order for the legal protection of loading and unloading of corporal crimes, criminal law should be positioned primum remedium rather than subsidiarity principle, ie the criminal law is placed in the position of ultimum remedium.

\section{References}

H. Jakson, John dan Mathis, Robert L. Managemen Sumber Daya Manusia, Buku I, Alih Bahasa Jimmy Sadeli dan Bayu Prawira Hic, Jakarta: Salemba Emban Patria, 2001.

Lilik Agung, A.M, Human Capital Competencies, Jakarta: Elex Media Komputindo, 2007.

Mulyadi S, Ekonomi Sumber Daya Manusia Dalam Perspektif Pembangunan, Jakarta: Rajaw ali Pers, 2003.

Mertokusumo, Sudikno, Mengenal Hukum, Suatu Pengantar, Yogyakarta: Liberty, 1988.

Nawawi, Hadari, Manajemen Sumber Daya Manusia untuk Bisnis yang Kompetitif, Yogyakarta: Gajah Mada University Press, 1997.

Reksodiputro, Mardjono, Tindak Pidana Korporasi dan Pertanggungjawabannya, Perubahan Wajah Pelaku Kejahatan di Indonesia, Pidato Dies Natalis Ke 47 PTIK MABES POLRI, Jakarta, 1993.

Rifai, Eddy, Eksploitasi Buruh Sebagai Kejahatan, "White Collar", dalam Harian Umum Suara Merdeka, Semarang: 19 November 1991. 


\section{Burhanuddin}

Susanto, I.S., Kejahatan White Collar dan Pembangunan Masyarakat Adil dan Makmur, Masalah-Masalah Hukum No.3, Semarang: Fakultas Hukum Universitas Diponegoro, 1991.

Sudarto, Hukum dan Hukum Pidana, Bandung: Alumni, 1981.

Sinaga, Marsen, Pengadilan Perburuhan di Indonesia (Tinjauan Hukum Kritis atas Undang-Undang PPHI), Yogyakarta: Perhimpunan Solidaritas Buruh, 2006.

Soekanto, Soerjono dan Purbacaraka, Purnadi, Perihal Kaidah Hukum, Bandung: Citra Aditya Bakti, 1993.

Tahija, Julius, Manajemen Sumber Daya Manusia, Yogyakarta: Andi Offset, 2005.

PB, Triton, Manajemen Sumber Daya Manusia Perspektif Partnership dan Kolektivitas, Yogyakarta: Tugu, 2007. 